\title{
Northern Tibetan Plateau cooling and aridification linked to Cenozoic global cooling: Evidence from $n$-alkane distributions of Paleogene sedimentary sequences in the Xining Basin
}

\author{
LONG LiQun $^{1,2}$, FANG XiaoMin ${ }^{1,3^{*}}$, MIAO YunFa ${ }^{1,4}$, BAI Yan ${ }^{1} \&$ WANG YongLi ${ }^{1,5}$ \\ ${ }^{1}$ Institute of Tibetan Plateau Research, Chinese Academy of Sciences, Beijing 100085, China; \\ ${ }^{2}$ Graduate University of Chinese Academy of Sciences, Beijing 100049, China; \\ ${ }^{3}$ Key Laboratory of Western China's Environmental Systems, Ministry of Education of China and College of Resources and Environment, Lan- \\ zhou University, Lanzhou 730000, China: \\ ${ }^{4}$ Key Laboratory of Desert and Desertification, Cold and Arid Regions Environmental and Engineering Research Institute, Chinese Academy of \\ Sciences, Lanzhou 730000, China, \\ ${ }^{5}$ Key Laboratory of Gas Geochemistry, Institute of Geology and Geophysics, Chinese Academy of Sciences, Lanzhou 730000, China
}

Received October 21, 2010; accepted March 1, 2011; published online April 13, 2011

\begin{abstract}
The Xining Basin on the northeastern Tibetan Plateau holds the longest continuous Cenozoic stratigraphic record in China. The sequence record contains considerable information on the history of Tibetan uplift and associated climatic change. In particular, high resolution $n$-alkane biomarker proxy and pollen records have been obtained from the Paleogene sediments of the Xiejia section of the basin. A combination of the $n$-alkane and palynological records reveals that the paleoclimate in the Xining Basin experienced a long-term cooling trend from 50.2 to $28.2 \mathrm{Ma}$ with a distinctive ecological event spanning 37.5 to $32.7 \mathrm{Ma}$. Since this ecological event, a vertical zonation of vegetation from lowland arid grasses, to middle-elevation subtropical broad-leaf plants, to high-elevation coniferous trees was established. We interpret that these changes in climate and vegetation were probably responses to a combination of long term global cooling since the Eocene climatic optimum and uplift of the surrounding mountains on the northern Tibetan Plateau in the early Cenozoic.
\end{abstract}

$n$-alkanes, Xining Basin, paleoenvironment, Tibetan uplift, aridification

Citation: $\quad$ Long L Q, Fang X M, Miao Y F, et al. Northern Tibetan Plateau cooling and aridification linked to Cenozoic global cooling: Evidence from $n$-alkane distributions of Paleogene sedimentary sequences in the Xining Basin. Chinese Sci Bull, 2011, 56: 1569-1578, doi: 10.1007/s11434-011-4469-0

The Tibetan Plateau is the most extensive region of elevated topography on Earth. Its global significance does not lie simply in the initiation and development of Asian aridification and monsoons [1-8], but also in ocean chemistry and global climate [9-13]. Thus, studies of the evolving paleoenvironment and paleoaltitude history of the Tibetan Plateau since the India-Eurasia collision can benefit our understanding of the link between tectonics and long term climate change.

Some previous studies have focused on the early elevation history of Tibet to provide constraints on the timing and

\footnotetext{
*Corresponding author (email: fangxm@itpcas.ac.cn)
}

magnitude of the early surface uplift of the region based on indicators of paleotopography in the geological record [14-19]. However, early Cenozoic elevation in the Tibetan Plateau is still poorly understood and documented. Moreover, paleoaltitude studies have focused on southern and central Tibet $[8,14,16,17,20,21]$. Such studies for northern Tibet are limited by poorly constrained ages for a long and continuous sequence of Cenozoic sediments. The lack of good age constraints on some deposits precludes the ability to determine the precise timing of surface uplift in northern Tibet. Further studies are clearly needed, particularly of northern Tibet, using more direct elevation proxies to chart the distribution and area of the uplifted plateau at a range of 
elevations throughout the Neogene.

Along the northeastern margin of the Tibetan Plateau, the Xining Basin holds the longest continuous Cenozoic stratigraphic record in China. The exceptionally long (52.0 to 17.0 Ma) continuous sedimentary succession in the basin provides an excellent opportunity to study the sedimentary signature of tectonic and climatic processes from the Eocene to the Oligocene. Stratigraphic, biostratigraphic, and magnetostratigraphic studies provide a basis for reconstructing the Cenozoic tectonic and climatic evolution of the Xining Basin with respect to adjacent regions of the northeastern Tibetan Plateau [22-26].

Reconstructing paleoenvironments using organic compounds constitutes a major field in the application of organic geochemistry. Plant $n$-alkanes from leaf waxes can be preserved in the geological record for a long time and register information on paleovegetation changes during historical periods. Analysis of those preserved in sediments is an established method for reconstructing the composition of past vegetation and thereby paleoenvironmental conditions $[27,28]$. The $n$-alkane ratio method of reconstructing paleovegetation and paleoclimate is advantageous because it is simple to perform and the size of samples required for $n$-alkane analysis is small. The strongly hydrophobic nature of the $n$-alkanes in sediment and their affinity for clays makes them immobile. Molecular stratigraphic approaches using plant $n$-alkanes have been employed widely for marine sediments [29-31], lacustrine and peat sediments [32-36] and loess-paleosol [28,37-39]. However, plant $n$-alkanes preserved in the Xining Basin have not been used to deduce paleoenvironmental information. In this study, we present well-dated organic geochemical and pollen data from the well-studied Xiejia section of the Xining Basin. Note that the interpretation of paleovegetation patterns from pollen can be problematic because of allochthonous input and long distance transport of some particular plant pollens are not easily preserved. The combination of organic geochemistry and classical pollen analysis has proven to be especially effective in detailed regional reconstructions of paleoenvironmental and paleoclimatic history [40-42]. Thus, we have combined $n$-alkane proxies with pollen records to reconstruct the paleoclimate history of the basin, thereby providing new insight into the temporal relationship between the northern Tibet uplift and global climate.

\section{Samples and methods}

\subsection{Study area}

The area of interest in this paper is located south of Xining on the northeastern part of the Tibetan Plateau in northwest China (Figure 1). The samples come from the Xiejia section $\left(101^{\circ} 52^{\prime} \mathrm{E}, 36^{\circ} 31^{\prime} \mathrm{N}, 2250 \mathrm{~m}\right.$ above sea level (a.s.l.)) in the Xining Basin. The basin is the transition zone from the Tibetan Plateau to the Loess Plateau, which is confined by
Dabanshan to the north, Lajishan to the south, Riyueshan to the west, and a small uplifted block to the east. The elevations of the surrounding mountains are $>3000 \mathrm{~m}$ a.s.l. In contrast, the elevation of most of the area inside the basin ranges from 1750 to $2600 \mathrm{~m}$ a.s.1. The mean annual temperature (MAT) and precipitation are $5-6^{\circ} \mathrm{C}$ and $350-500$ $\mathrm{mm}$, respectively. Precipitation occurs mainly in summer. The native vegetation in the present basin has a dramatic vertical variation because of the large elevation differences between the valleys and surrounding mountains. Stipa bungeana, Stipa glareosa and Artemisia gmelinii are distributed mainly in areas below $2600 \mathrm{~m}$. Picea crassifolia and Picea wilsonii are not abundant and are distributed mainly on shady slopes at 2600-3000 m. Shrubs, including Potentilla fruticosa, Salix oritrepha and Rhododendron, grow in areas above $3000 \mathrm{~m}$. The alpine meadow plant, Kobresia bipartite is widely distributed in areas above 3200 $\mathrm{m}$ [43].

Eocene to mid-Miocene deposition in the Xining Basin was characterized by the slow accumulation of lacustrine saline playa to distal alluvial fan deposits [25]. The 819-m-thick Xiejia section can be divided into six formations, from oldest to youngest: Qijiachuan (thicknesses 20-69 m), Honggou (69-224 m), Mahalagou (224-504 m), Xiejia (504-667 m), Chetougou (667-778 m) and Xianshuihe $(778-819 \mathrm{~m})$. The lower part $(0-450 \mathrm{~m})$ of the section consists of roughly regular alternations of laterally-continuous gypsum layers and red mudstone intervals of lacustrine saline playa. The gypsum layers occasionally preserve greenish-grey lacustrine mud. The upper part (450-819 m) of the section is characterized by red beds of mudstone and siltstone from flood plains and distal alluvial fans, occasionally intercalated with thin layers of fluvial channel sandstone deposits [25]. A final gypsum layer occurs at about $500 \mathrm{~m}$ in the measured section (Figure 2). The age model for the section has been established on the basis of magnetostratigraphy [25]. This study focuses on the portion from the top of the Honggou Formation to the bottom of the Xiejia Formation, from 70.5 to $546 \mathrm{~m}$ in the section, corresponding to a time interval of ca. 50.2 to $28.2 \mathrm{Ma}$ (Figure 2).

\subsection{Samples and methods}

We collected 43 samples for geochemical analysis, with an interval of $\sim 10 \mathrm{~m}$ from the Xiejia section (see stratigraphic positions, ages and sequences in Figure 2; Table 1). To better constrain the existing record in time and provide a new detailed geochemical analysis, sampling for plant $n$-alkanes was performed at higher resolution for the interval, including the Eocene-Oligocene transition. The samples (each 20 g) were carefully ground to pass through an 80 mesh and extracted with $\mathrm{CHCl}_{3}$ in a Soxhlet apparatus for $72 \mathrm{~h}$. The extracts were concentrated and separated into aliphatic, aromatic and polar fractions using chromatography on silica 


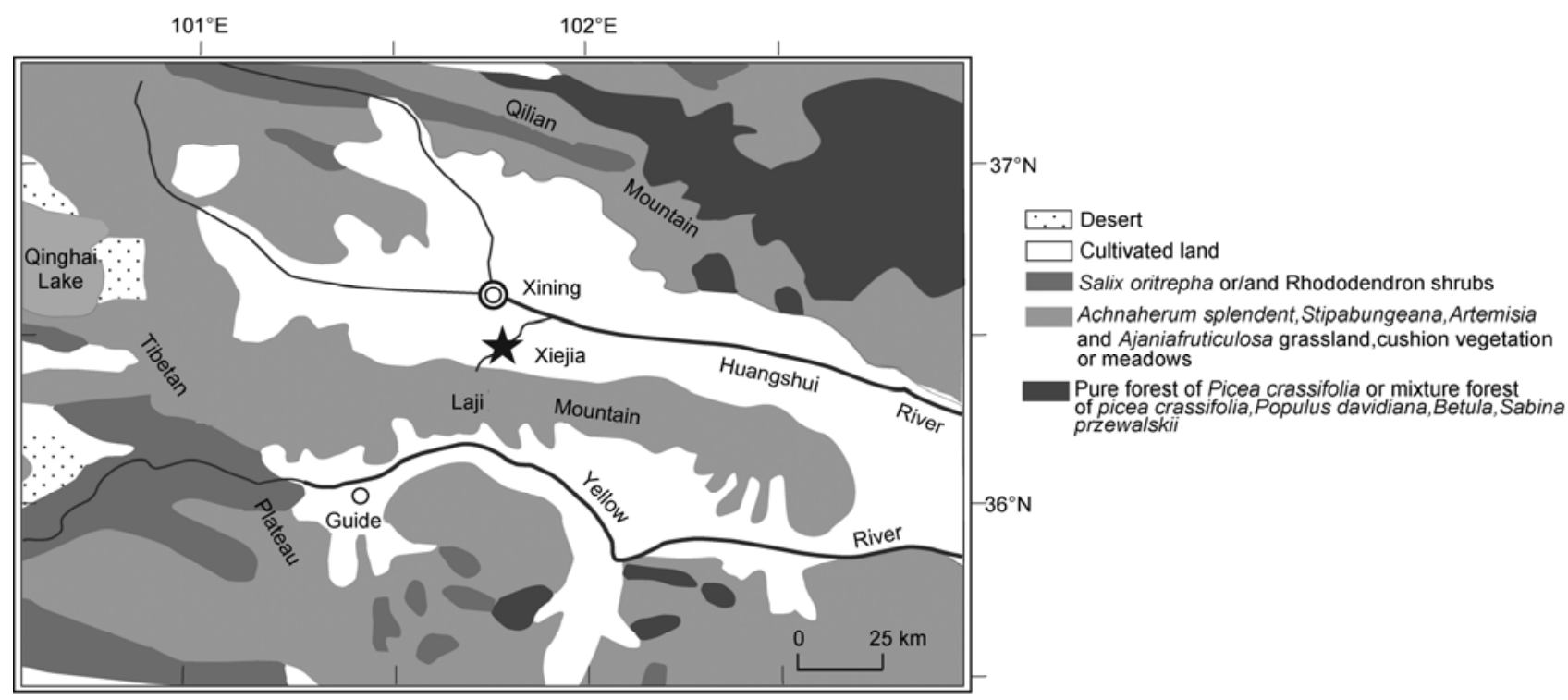

Figure 1 Geography and simplified vegetation distribution map of the Xining Basin.

gel and alumina. After natural air-drying and dilution using $\mathrm{CHCl}_{3}$, the alkanes were analyzed using gas chromatography mass spectrometry (GC-MS). A blank sample was checked using the same procedures to monitor for contamination.

The analysis of the organic matter was carried out in the Key Laboratory of Gas Geochemistry, Institute of Geology and Geophysics, Chinese Academy of Sciences. GC-MS was performed using a Hewlett-Packard (HP) 5973 mass spectrometer in electron ionization mode (EI $70 \mathrm{eV})$ interfaced directly with a HP-6890 gas chromatography equipped with a HP-5MS fused silica column $(30 \mathrm{~m} \times 0.25 \mathrm{~mm}$ i.d.; $0.25 \mu \mathrm{m}$ film thickness). The oven temperature was from 80 to $300^{\circ} \mathrm{C}$ at $5^{\circ} \mathrm{C} / \mathrm{min}$ and held at $280^{\circ} \mathrm{C}$ for $20 \mathrm{~min}$ utes. Helium was the carrier gas.

Samples from the Xiejia section were chosen for spore and pollen analysis at 2-3 m intervals. About 150-350 g of each sample were treated with $36 \% \mathrm{HCl}$ and $73 \% \mathrm{HF}$, respectively. Furthermore, the spores and pollen were concentrated after the remaining material was passed through a $10 \mu \mathrm{m}$ mesh in an ultrasonic bath. The prepared specimens were mounted with glycerol and examined at $400 \times$ magnification (detailed results are shown in another article ${ }^{1)}$ ).

\section{Results}

\section{$2.1 \quad n$-Alkanes}

(i) Distributions and contents. The distribution of $n$ alkanes ranges from $\mathrm{C}_{16}$ to $\mathrm{C}_{35}$, maximizing at $\mathrm{C}_{29}$ or $\mathrm{C}_{31}$. In most samples, short-chain compounds $\left(<\mathrm{C}_{21}\right)$ were low or nearly absent, probably implying limited contributions from microbes, algae and bacteria in the playa system. A marked odd/even carbon predominance is observed above $\mathrm{C}_{22}$ throughout the Xiejia section from 50.2 to $28.2 \mathrm{Ma}$ (Figure 3 ). High proportions of long chain $C_{27}$ to $C_{31}$ members are typical of terrestrial higher plants, where they occur as the main components of plant waxes. The Carbon Preference Index, CPI $\left\{\left[\left(\mathrm{C}_{25}+\mathrm{C}_{27}+\mathrm{C}_{29}+\mathrm{C}_{31}+\mathrm{C}_{33}\right) /\left(\mathrm{C}_{24}+\mathrm{C}_{26}+\mathrm{C}_{28}+\right.\right.\right.$ $\left.\mathrm{C}_{30}+\mathrm{C}_{32}\right)+\left(\mathrm{C}_{25}+\mathrm{C}_{27}+\mathrm{C}_{29}+\mathrm{C}_{31}+\mathrm{C}_{33}\right) /\left(\mathrm{C}_{26}+\mathrm{C}_{28}+\mathrm{C}_{30}+\right.$ $\mathrm{C}_{32}+\mathrm{C}_{34}$ )]/2\} ranges from 1.45 to 6.23 (Table 1). These characteristics are consistent for all the depositional sequences in the section and in accordance with a terrestrial higher plant origin for the $n$-alkanes [33,44-46].

The total content of odd-numbered long chain $n$-alkanes $\left(\mathrm{C}_{27}+\mathrm{C}_{29}+\mathrm{C}_{31}+\mathrm{C}_{33}\right)$ shows a generally declining trend from 1.33 to $0.05 \mu \mathrm{g} / \mathrm{g}$ with some oscillations with increasing depth throughout the section, corresponding to 50.2 to 28.2 Ma (Figure 2; Table 1). The values remained relatively high and oscillate from 0.4 to $1.33 \mu \mathrm{g} / \mathrm{g}$ from 50.2 to 37.5 Ma. They begin to decrease very quickly after $37.5 \mathrm{Ma}$, ranging from 0.05 to $0.5 \mu \mathrm{g} / \mathrm{g}$, and then remain very low for the rest of the section.

(ii) $n$-Alkane maximum $\left(C_{\max }\right)$. Woody plant $n$-alkane distributions are dominated by $\mathrm{C}_{27}$ or $\mathrm{C}_{29}$, whereas grasses are preferentially dominated by $\mathrm{C}_{31}$. Hence, carbon distribution patterns have been used to estimate changes in vegetation type and therefore paleoclimate. It can be deduced that $\mathrm{C}_{31}$-dominated sediment samples imply that the main vegetation type was grassland, whereas a $\mathrm{C}_{27}$ or $\mathrm{C}_{29}$ dominance indicates a prevalence of woody plants. That is to say, the $\mathrm{C}_{31}, \mathrm{C}_{27}$ and $\mathrm{C}_{29}$ homologues can represent the relative biomass of woody vegetation and grass vegetation $[27,37$, $38,47,48]$. 


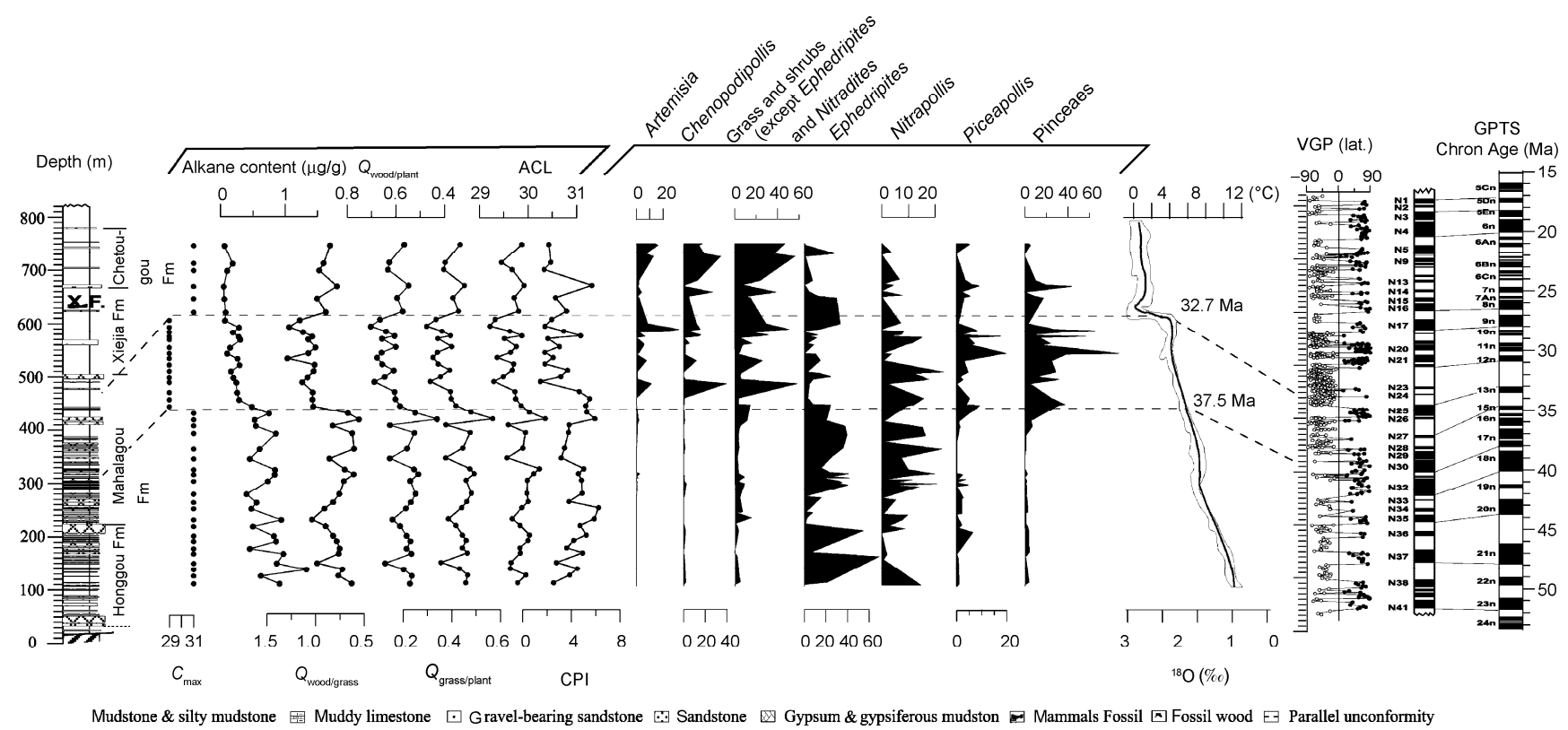

Figure 2 Time series of $n$-alkane proxies and pollen diagram showing abundance (\%) of major floral components (detailed results are presented in another article $\left.^{2)}\right) v s$. stable isotope marine records. Age model from Dai [25]. Alkanes content $(\mu \mathrm{g} / \mathrm{g})=\mathrm{C}_{27}+\mathrm{C}_{29}+\mathrm{C}_{31}+\mathrm{C}_{33} ; Q_{\text {wood/grass }}=\mathrm{C}_{27} / \mathrm{C}_{31} ; Q_{\text {grass } p l a n t}=\mathrm{C}_{31} /\left(\mathrm{C}_{27}+\right.$ $\left.\mathrm{C}_{29}+\mathrm{C}_{31}\right) ; Q_{\text {woodplant }}=\left(\mathrm{C}_{27}+\mathrm{C}_{29}\right) /\left(\mathrm{C}_{27}+\mathrm{C}_{29}+\mathrm{C}_{31}\right) ; \mathrm{CPI}=\left[\left(\mathrm{C}_{25}+\mathrm{C}_{27}+\mathrm{C}_{29}+\mathrm{C}_{31}+\mathrm{C}_{33}\right) /\left(\mathrm{C}_{24}+\mathrm{C}_{26}+\mathrm{C}_{28}+\mathrm{C}_{30}+\mathrm{C}_{32}\right)+\left(\mathrm{C}_{25}+\mathrm{C}_{27}+\mathrm{C}_{29}+\mathrm{C}_{31}+\mathrm{C}_{33}\right) /\left(\mathrm{C}_{26}+\mathrm{C}_{28}\right.\right.$ $\left.\left.+\mathrm{C}_{30}+\mathrm{C}_{32}+\mathrm{C}_{34}\right)\right] / 2 ; \mathrm{ACL}=\left(27 \times \mathrm{C}_{27}+29 \times \mathrm{C}_{29}+31 \times \mathrm{C}_{31}+33 \times \mathrm{C}_{33}\right) /\left(\mathrm{C}_{27}+\mathrm{C}_{29}+\mathrm{C}_{31}+\mathrm{C}_{33}\right)$.

From 50.2 to $37.5 \mathrm{Ma}$, the long chain $n$-alkanes $\left(>\mathrm{C}_{22}\right)$ throughout the section are characterized by a rather invariant distribution pattern, with $\mathrm{C}_{31}$ dominant. In contrast, $\mathrm{C}_{29}$ dominates from 37.5 to $32.7 \mathrm{Ma}$ (Figures 2 and 3). $\mathrm{C}_{31}$ dominance occurs again from 32.7 to $28.2 \mathrm{Ma}$.

The $C_{\max }$ variation throughout the section shows that $\mathrm{C}_{31}$ dominates the sediments from 50.2 to $37.5 \mathrm{Ma}$. All the samples should expect grass to be dominant during this phase; $\mathrm{C}_{29}$ n-alkane dominates from 37.5 to $32.7 \mathrm{Ma}$, suggesting a predominance of trees in the Xining Basin; a $\mathrm{C}_{31}$ dominance occurs again during 32.7 to $28.2 \mathrm{Ma}$, implying a grass dominance. The $C_{\max }$ shifts at 37.5 and 32.7 Ma might be related to vegetation changes occurring in response to climate change.

(iii) $\mathrm{C}_{27} / \mathrm{C}_{31},\left(\mathrm{C}_{27}+\mathrm{C}_{29}\right) /\left(\mathrm{C}_{27}+\mathrm{C}_{29}+\mathrm{C}_{31}\right)$ and $\mathrm{C}_{31} /\left(\mathrm{C}_{27}+\right.$ $\mathrm{C}_{29}+\mathrm{C}_{31}$ ) ratio. Modern molecule organic geochemistry has demonstrated that the ratio of $\mathrm{C}_{27} / \mathrm{C}_{31}$ of $n$-alkanes is mostly indicative of the relative proportion of wood plants to grass vegetation $[35,37,49]$. The variation in the ratio of $\mathrm{C}_{27} / \mathrm{C}_{31} n$-alkane in the lacustrine sediments has been demonstrated to be related to the dominant land types shifting between woody plants and grasses [27,33].

For further comparisons, we use $Q_{\text {grass } / \text { plant }}=\mathrm{C}_{31} /$ $\left(\mathrm{C}_{27}+\mathrm{C}_{29}+\mathrm{C}_{31}\right)$ and $Q_{\text {wood/plant }}=\left(\mathrm{C}_{27}+\mathrm{C}_{29}\right) /\left(\mathrm{C}_{27}+\mathrm{C}_{29}+\mathrm{C}_{31}\right)$, to represent the relative $n$-alkane abundance of grass and woody plants in the samples respectively, because the $Q_{\text {grass/plant }}$ and $Q_{\text {wood/plant }}$ indices have been widely believed also to represent the relative abundance of grass and woody vegetation $[39,50]$.
Figure 2 displays the $\mathrm{C}_{27} / \mathrm{C}_{31}$ and $\left(\mathrm{C}_{27}+\mathrm{C}_{29}\right) /\left(\mathrm{C}_{27}+\mathrm{C}_{29}+\right.$ $\mathrm{C}_{31}$ ) ratio curves in the section, which are essentially parallel each other, with lower values from 50.2 to $37.5 \mathrm{Ma}$. In contrast, the value of $\mathrm{C}_{31} /\left(\mathrm{C}_{27}+\mathrm{C}_{29}+\mathrm{C}_{31}\right)$ is relatively high from 50.2 to $37.5 \mathrm{Ma}$, showing a higher proportion of grass relative to woody plants [39]. With the change in climate and environment, the values of $\mathrm{C}_{27} / \mathrm{C}_{31}$ and $\left(\mathrm{C}_{27}+\mathrm{C}_{29}\right) /\left(\mathrm{C}_{27}\right.$ $\left.+\mathrm{C}_{29}+\mathrm{C}_{31}\right)$ show a marked increase, whereas $\mathrm{C}_{31} /\left(\mathrm{C}_{27}+\right.$ $\mathrm{C}_{29}+\mathrm{C}_{31}$ ) decreased significantly since $37.5 \mathrm{Ma}$, implying that the vegetation changed from grass to wood dominance. Then, $\mathrm{C}_{27} / \mathrm{C}_{31}$ and $\left(\mathrm{C}_{27}+\mathrm{C}_{29}\right) /\left(\mathrm{C}_{27}+\mathrm{C}_{29}+\mathrm{C}_{31}\right)$ ratios stay generally high between 37.5 and $32.7 \mathrm{Ma}$, suggesting a predominance of trees over the Xining Basin.

At 32.7 Ma, the $\mathrm{C}_{27} / \mathrm{C}_{31}$ and $\left(\mathrm{C}_{27}+\mathrm{C}_{29}\right) /\left(\mathrm{C}_{27}+\mathrm{C}_{29}+\mathrm{C}_{31}\right)$ ratios began to decrease again and stayed relatively low from 32.7 to $28.2 \mathrm{Ma}$, with the $\mathrm{C}_{31} /\left(\mathrm{C}_{27}+\mathrm{C}_{29}+\mathrm{C}_{31}\right)$ ratio increasing gradually, showing gradual development of grassland after 32.7 Ma.

(iv) Average chain length (ACL). The ACL values $\left[\left(27 \mathrm{C}_{27}+29 \mathrm{C}_{29}+31 \mathrm{C}_{31}+33 \mathrm{C}_{33}\right) /\left(\mathrm{C}_{27}+\mathrm{C}_{29}+\mathrm{C}_{31}+\mathrm{C}_{33}\right)\right]$ indicate the concentration-weighted mean chain length of the $\mathrm{C}_{27}$ to $\mathrm{C}_{33}$ $n$-alkanes, and might reflect local temperature variation [51,52], as well as different vegetation types [32,41,42]. Plants in warmer/wetter areas have higher values than those in colder/drier areas [42]. The values decrease from 30.4 to 29.2 , with some oscillation, with increasing thickness in the section (Figure 2; Table 1). They vary from 29.6 to 30.4 and stay generally higher during the 50.2 to $37.5 \mathrm{Ma}$ period. From $37.5 \mathrm{Ma}$, the values apparently decrease and vary 


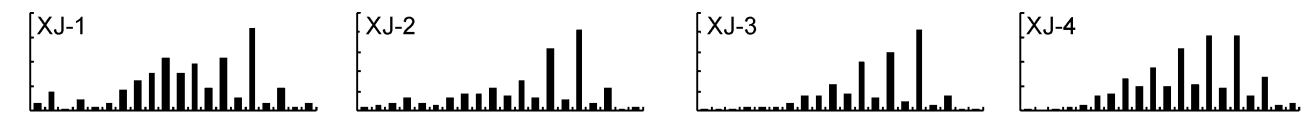
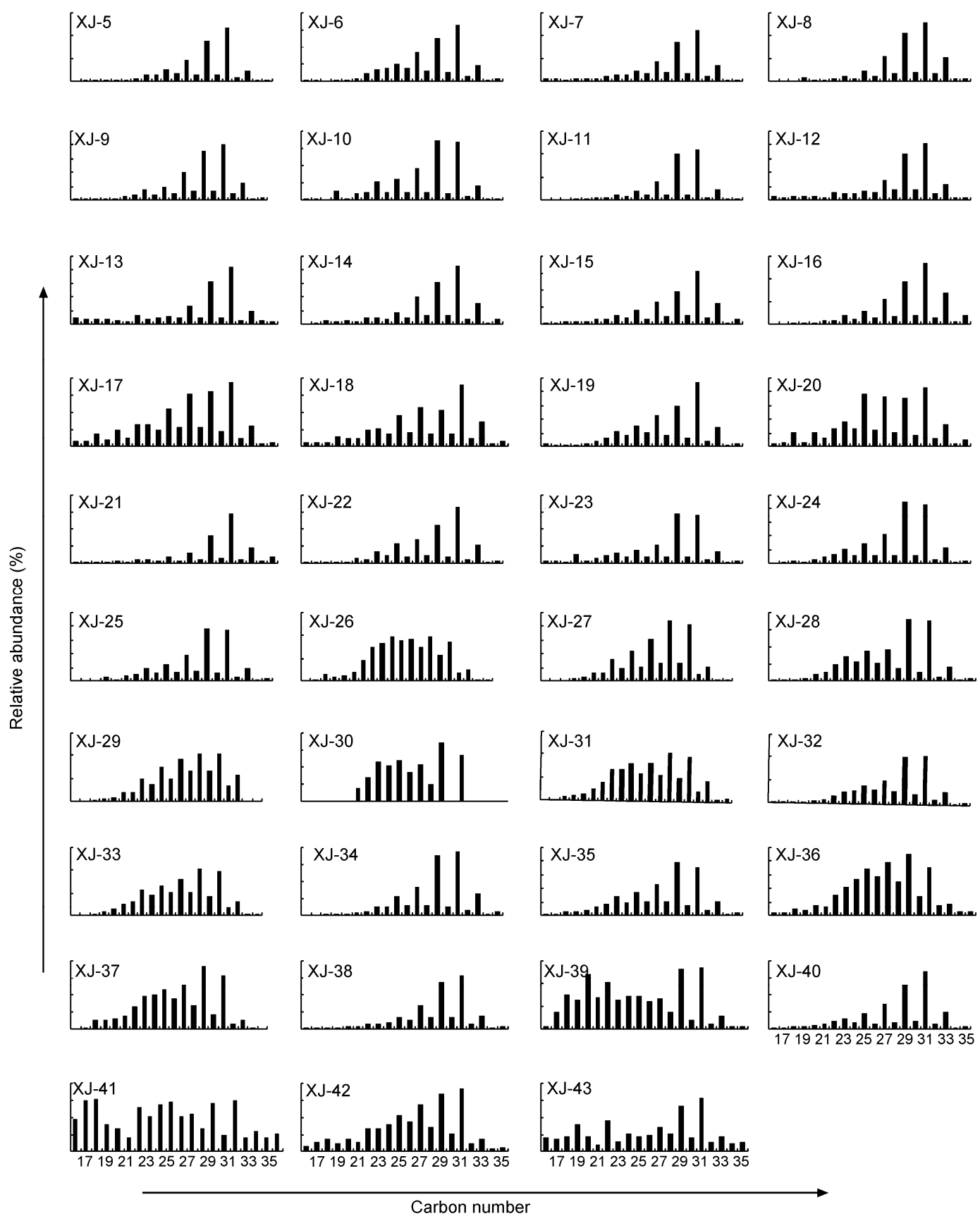

Figure 3 Relative abundance (vertical axis) and distributions of $n$-alkanes from Xiejia section.

from 29.2 to 29.9 between $37.5-28.2 \mathrm{Ma}$, suggesting that the climate gradually became cooler from $37.5 \mathrm{Ma}$, resulting in woody plant development.

\subsection{Pollen record}

From fossil pollen analyses of the section, we have selected seven representative palynological proxies for better comparisons with the $n$-alkane proxies (Figure 2). The xerophytic shrubs Ephedripites and Nitrariadites, the drought- enduring herbaceous plants Chenopodipollis and Artemisia, grasses and shrubs (except Ephedripites and Nitrariadites) and the Piceapollenites and Pinceae conifers were selected as being diagnostic pollen indices for reconstructing environmental 
Table $1 n$-Alkanes data (see text for definitions) in samples from the Xiejia section ${ }^{\text {a) }}$

\begin{tabular}{|c|c|c|c|c|c|c|c|c|c|}
\hline Phase & Sample & Age (Ma) & $C_{\max }$ & Alkane content $(\mu \mathrm{g} / \mathrm{g})$ & $\mathrm{C}_{29} / \mathrm{C}_{31}$ & $\left(\mathrm{C}_{27}+\mathrm{C}_{29}\right) /\left(\mathrm{C}_{27}+\mathrm{C}_{29}+\mathrm{C}_{31}\right)$ & $\mathrm{C}_{31} /\left(\mathrm{C}_{27}+\mathrm{C}_{29}+\mathrm{C}_{31}\right)$ & $\mathrm{ACL}$ & CPI \\
\hline \multirow{22}{*}{ I } & $\mathrm{XJ}-1$ & 50.2 & 31 & 0.91 & 0.63 & 0.54 & 0.46 & 29.79 & 2.54 \\
\hline & $\mathrm{XJ}-2$ & 49.4 & 31 & 0.62 & 0.77 & 0.53 & 0.47 & 29.96 & 3.87 \\
\hline & $\mathrm{XJ}-3$ & 48.9 & 31 & 1.33 & 0.72 & 0.57 & 0.43 & 29.64 & 4.49 \\
\hline & $\mathrm{XJ}-4$ & 48.4 & 31 & 0.87 & 0.98 & 0.64 & 0.36 & 29.65 & 2.78 \\
\hline & $\mathrm{XJ}-5$ & 47.7 & 31 & 0.97 & 0.76 & 0.54 & 0.46 & 29.84 & 4.92 \\
\hline & $\mathrm{XJ}-6$ & 47.3 & 31 & 0.45 & 0.75 & 0.56 & 0.44 & 29.83 & 3.62 \\
\hline & $\mathrm{XJ}-7$ & 46.7 & 31 & 0.86 & 0.78 & 0.54 & 0.46 & 30.00 & 4.19 \\
\hline & $\mathrm{XJ}-8$ & 46.3 & 31 & 0.83 & 0.82 & 0.56 & 0.44 & 30.03 & 5.23 \\
\hline & XJ-9 & 45.6 & 31 & 0.50 & 0.90 & 0.58 & 0.42 & 29.84 & 4.72 \\
\hline & XJ-10 & 45.0 & 31 & 0.94 & 1.04 & 0.61 & 0.39 & 29.68 & 5.89 \\
\hline & XJ-11 & 44.2 & 31 & 0.48 & 0.91 & 0.56 & 0.44 & 29.87 & 6.23 \\
\hline & $\mathrm{XJ}-12$ & 43.7 & 31 & 0.56 & 0.82 & 0.54 & 0.46 & 30.01 & 3.80 \\
\hline & XJ-13 & 43.0 & 31 & 0.40 & 0.75 & 0.52 & 0.48 & 29.98 & 4.89 \\
\hline & XJ-14 & 42.0 & 31 & 0.73 & 0.71 & 0.54 & 0.46 & 29.99 & 4.84 \\
\hline & XJ-15 & 41.5 & 31 & 0.84 & 0.61 & 0.51 & 0.49 & 30.12 & 4.57 \\
\hline & XJ-16 & 41.1 & 31 & 0.85 & 0.70 & 0.52 & 0.48 & 30.24 & 5.03 \\
\hline & XJ-17 & 40.3 & 31 & 0.45 & 0.86 & 0.62 & 0.38 & 29.57 & 3.16 \\
\hline & XJ-18 & 39.5 & 31 & 0.61 & 0.60 & 0.55 & 0.45 & 29.89 & 3.44 \\
\hline & XJ-19 & 38.3 & 31 & 0.86 & 0.62 & 0.52 & 0.48 & 29.95 & 3.75 \\
\hline & XJ-20 & 38.1 & 31 & 0.55 & 0.82 & 0.62 & 0.38 & 29.59 & 3.81 \\
\hline & XJ-21 & 37.7 & 31 & 0.53 & 0.55 & 0.43 & 0.57 & 30.36 & 5.94 \\
\hline & XJ-22 & 37.5 & 31 & 0.75 & 0.67 & 0.52 & 0.48 & 30.03 & 5.27 \\
\hline \multirow{15}{*}{ II } & XJ-23 & 37.6 & 29 & 0.49 & 1.02 & 0.58 & 0.42 & 29.86 & 5.19 \\
\hline & XJ-24 & 35.7 & 29 & 0.29 & 1.03 & 0.60 & 0.40 & 29.75 & 5.51 \\
\hline & XJ-25 & 34.9 & 29 & 0.26 & 1.03 & 0.60 & 0.40 & 29.73 & 4.65 \\
\hline & XJ-26 & 34.4 & 29 & 0.25 & 1.14 & 0.69 & 0.31 & 29.30 & 1.45 \\
\hline & XJ-27 & 34.2 & 29 & 0.20 & 1.08 & 0.65 & 0.35 & 29.50 & 3.14 \\
\hline & XJ-28 & 34.1 & 29 & 0.16 & 1.02 & 0.61 & 0.39 & 29.68 & 3.69 \\
\hline & XJ-29 & 33.9 & 29 & 0.30 & 1.01 & 0.66 & 0.34 & 29.71 & 1.83 \\
\hline & XJ-30 & 33.7 & 29 & 0.26 & 1.29 & 0.68 & 0.32 & 29.37 & 2.50 \\
\hline & XJ-31 & 33.6 & 29 & 0.10 & 1.08 & 0.66 & 0.34 & 29.64 & 1.81 \\
\hline & XJ-32 & 33.4 & 29 & 0.15 & 1.00 & 0.60 & 0.40 & 29.76 & 3.02 \\
\hline & XJ-33 & 33.2 & 29 & 0.31 & 1.08 & 0.66 & 0.34 & 29.52 & 2.06 \\
\hline & XJ-34 & 33.1 & 29 & 0.28 & 1.03 & 0.60 & 0.40 & 29.87 & 4.76 \\
\hline & XJ-35 & 32.9 & 29 & 0.19 & 1.13 & 0.64 & 0.36 & 29.63 & 3.37 \\
\hline & XJ-36 & 32.8 & 29 & 0.29 & 1.27 & 0.70 & 0.30 & 29.22 & 1.83 \\
\hline & XJ-37 & 32.7 & 29 & 0.07 & 1.16 & 0.66 & 0.34 & 29.33 & 2.38 \\
\hline \multirow{6}{*}{ III } & XJ-38 & 32.2 & 31 & 0.08 & 0.89 & 0.57 & 0.43 & 29.81 & 3.61 \\
\hline & XJ-39 & 31.7 & 31 & 0.06 & 0.98 & 0.59 & 0.41 & 29.71 & 2.70 \\
\hline & XJ-40 & 31.1 & 31 & 0.05 & 0.78 & 0.55 & 0.45 & 29.92 & 5.68 \\
\hline & XJ-41 & 29.6 & 31 & 0.11 & 0.96 & 0.63 & 0.37 & 29.67 & 1.76 \\
\hline & XJ-42 & 28.9 & 31 & 0.19 & 0.92 & 0.63 & 0.37 & 29.45 & 2.31 \\
\hline & XJ-43 & 28.2 & 31 & 0.06 & 0.85 & 0.57 & 0.43 & 29.87 & 2.15 \\
\hline
\end{tabular}

a) The three phases are divided by the temporal variations from these proxie.

changes in this region.

From ca. 50 to $37.5 \mathrm{Ma}$, the pollen assemblages show that the xerophytic shrubs are most abundant, including Ephedripites (0-70\%, avg. 30\%) and Nitrariadites (2\%-22\%, avg. $14 \%$ ). Various warm-temperate to subtropical decidu- ous broad leaf plants are also relatively high (0-70\%, avg. 25\%), mainly including Ulmipollenites, Jianghanpollis, Proteacidites, Lonicerapollis, Meliaceoidites, Euphorbiacites, Quercoidites, Cupuliferoipollenites, Betulaceoipollenites, Juglanspollenites, and Salixipollenites, whereas 
herbaceous plants, like Graminidites, Cyperaceaepollis, Sparganiaceaepollenite, Persicarioipollis, and Labitricolpites, have a very low percentage. Conifers are almost absent (detailed results of which will be the subject of future work).

From ca. 37.5 to $33 \mathrm{Ma}$, Ephedripites (2\%-24\%) and $\mathrm{Ni}$ trariadites $(0-11 \%)$ declined abruptly in conjunction with a drastic increase in Pinceae (4\%-80\%), in an especially cool climate Piceapollenites (0-20\%). Other conifers also include Pinus, Podocarpus, Tsuga and Cedrus in low proportions. Arid types and drought-enduring herbaceous plants, Chenopodipollis (0-40\%) and Artemisia (0-11\%), first appear within the sequence. The warm- temperate and subtropical deciduous components (3\%-28\%, average 16\%) visibly decrease.

From ca. 33 to $28 \mathrm{Ma}$, grass and shrubs increased dramatically and became most abundant (5\%-60\%), including mainly Chenopodipollis (2\%-45\%) and Artemisia (2\%-30\%). The conifers, especially Picea, show a large decrease (0-8\%). Ephedripites (0-32\%) and Nitrariadites (0-7\%) decrease slightly. The warm-temperate and subtropical deciduous components (2\%-20\%, average 6\%) largely decrease.

\section{Discussion}

From the results above, it is clear that these different $n$-alkane indices show a very similar trend from 50.2 to 28.2 Ma in the Xiejia section. They suggest that vegetation responded to climate related changes, notably temperature and humidity, in the Xining Basin. A better understanding of vegetation and climate variability in the Xining Basin can be gained by combining $n$-alkane proxies and palynological records for the same time intervals. According to the $n$-alkane and palynological proxies, the paleovegetation and paleoclimatic evolution of the basin can be divided roughly into three major phases. Figure 2 and Table 1 illustrate the variability in these records, showing three evolutionary phases of paleovegetation and paleoclimate, and two marked ecological shifts at about 37.5 and 32.7 Ma. Based on the dated Xiejia section, the three major phases are assigned to corresponding major marine isotope stages $[53,54]$.

In Phase 1 (ca. 50.2 to 37. $5 \mathrm{Ma}$, samples XJ-1 to XJ-22), the distinctive predominance of $\mathrm{C}_{31}$ and relatively high $\mathrm{C}_{31} /\left(\mathrm{C}_{27}+\mathrm{C}_{29}+\mathrm{C}_{31}\right)$ ratios might have resulted from a greater contribution from grasses, which tend to have longer chain compounds and produce a higher proportion of $\mathrm{C}_{31}$. We suspect that grasses or plants with waxy leaves that reduce water loss and have longer chain lengths were in greater abundance during the arid conditions of this phase. Thus, a higher proportion of $\mathrm{C}_{31}$ during this phase is explained by aridity.

A warm/humid climate favors plant growth, which can be expected to result in a high proportion of odd $n$-alkanes.
In contrast, a dry and cold climate limits plant productivity and results in a low proportion of odd $n$-alkanes [38]. The odd $n$-alkane content is observed to be generally high and in fact reaches maximum values during this phase, suggesting relatively high plant productivity and a relatively warm or wet climate. Furthermore, the ACL values stay generally higher in this phase indicating a warm climate, which favors plant growth.

ACL, $\mathrm{C}_{31} /\left(\mathrm{C}_{27}+\mathrm{C}_{29}+\mathrm{C}_{31}\right)$ ratio and CPI show parallel changes throughout the section (Figure 2 ). The $C_{31}$ concentration significantly affects the value of CPI, showing a positive relationship. It seems that high CPI results mainly from the content of higher plant long chain $n$-alkanes. Hence, both CPI and ACL increase as $\mathrm{C}_{31} /\left(\mathrm{C}_{27}+\mathrm{C}_{29}+\mathrm{C}_{31}\right)$ increases. One explanation for these similarities is the relative increase in the $\mathrm{C}_{31}$ contribution during warm stages, with consequent increases in ACL, $\mathrm{C}_{31} /\left(\mathrm{C}_{27}+\mathrm{C}_{29}+\mathrm{C}_{31}\right)$ and CPI. A similar trend was observed in the Chinese Loess Plateau profile [38]. Therefore, all three parameters indicate increased grass cover during warm stages.

The higher proportion of $\mathrm{C}_{31}$ that occurred here most likely implies a warm climate. Other researchers have observed similar responses. For example, Hinrichs et al. [55] argued that the increase in $\mathrm{C}_{31} n$-alkane released from the western United States during MIS 5 could be interpreted as a response to increased temperature. Kawamura et al. [56] analyzed the $n$-alkanes from ten broad-leaf plant species collected from tropical $\left(6^{\circ} \mathrm{S}\right)$, subtropical $\left(27^{\circ} \mathrm{N}\right)$ and temperate $\left(43^{\circ} \mathrm{N}\right)$ regions and found a systematic decrease in the relative percentage of $\mathrm{C}_{31}$ from tropical to the temperate, also suggesting that $\mathrm{C}_{31}$ is related to temperature. Thus, these $n$-alkane proxies are in accord with an obvious warm and dry climate during this period.

The pollen assemblage from this phase shows that Ephedripites and Nitrariadites were most abundant with some subtropical deciduous taxa (Figure 2), lending further support to the inference above a hot and dry climate in this phase. Generally, a hot-dry climate also favors grass growth. However, we do not observe high contents of grasses in our pollen spectra, except the inference of a high contribution of grass from $n$-alkane proxies above. Grasses identified from this part of the stratigraphy are largely Gramionidites, Sparganiaceaepollenites, Potamogetonacidites, and Cyperaceaepollis. These types of grasses have poor stratigraphic preservation. Pollens of grasses Chenopodipollis and Artemisia can be preserved in sediments for a long time, but they only appeared as important taxa in the ecologic system during the late Eocene and Oligocene [57-59]. We argue that these two points may have resulted in low grass contents in the early Cenozoic pollen record.

In Phase 2 (ca. 37.5 to $32.7 \mathrm{Ma}$, samples $\mathrm{XJ}-23$ to $\mathrm{XJ}-37$ ), the shift in the dominant peak from $\mathrm{C}_{31}$ to $\mathrm{C}_{29}$ might be related to vegetation changes that occurred in response to climate change. The $\mathrm{C}_{27} / \mathrm{C}_{31}$ and $\left(\mathrm{C}_{27}+\mathrm{C}_{29}\right) /\left(\mathrm{C}_{27}+\mathrm{C}_{29}+\right.$ $\left.\mathrm{C}_{31}\right)$ ratios largely increased, whereas $\mathrm{C}_{31} /\left(\mathrm{C}_{27}+\mathrm{C}_{29}+\mathrm{C}_{31}\right)$ 
and ACL values declined abruptly, indicating a predominance of trees over the Xining Basin. This suggests that the climate was relatively colder and humid during this phase. The long chain odd $n$-alkane component began to decrease very quickly from $37.5 \mathrm{Ma}$ and the values remained very low for the rest of the section. The variation in long chain $n$-alkane content follows other $n$-alkane proxies, implying that 37.5 Ma may represent a marked ecological shift when the climate began to limit plant productivity, probably as a result of decreased temperatures.

This inference is supported further by pollen records. The most striking change is the sudden appearance and increasing abundance of cool-climate conifer pollens (in particular Picea) and grasses of Chenopodipollis and Artemisia during this period, along with the abrupt decline in warm-temperate and subtropical deciduous plants. After the sudden appearance of conifers, they constituted a major component of the palynological record. The relatively high abundances of Picea pollen occurred here, suggesting that the source plants grew in the vicinity of the study area at the time of deposition. Grasses of Chenopodipollis and Artemisia prefer a dry-cold climate and are demonstrated to appear mostly from the late Eocene to Oligocene [57-59], agreeing with our record. Thus, the pollen assemblage here indicates a vertical zone of vegetation occurrence during this interval, namely Ephedripites, Nitradites, Chenopodipollis and Artemisia growing at lower elevations, with warm-subtropical and warm temperate types at higher topographical regions, and cold temperate types only surviving at the highest elevations. It is estimated that forest or forest-steppe vegetation dominated the basin during this interval, with a spruce forest growing in the mountain areas, and drought-enduring shrubs and herbs spreading around the valleys, mountainous areas, glades and slopes. The climate was relatively humid and had a relatively low temperature.

A molecular fossil study of modern forest vegetation and underlying soil from the semi-arid area of Xinglong Mountain near Lanzhou in the western part of the Loess Plateau showed that branches and leaves of deciduous broad-leaf trees are dominated by $\mathrm{C}_{27}$ homologues whereas needle-leaved evergreen trees and leaves are dominate by $\mathrm{C}_{29}$ homologs [39]. The greater abundances of these $\mathrm{C}_{29}$ $n$-alkanes compounds from the Xiejia section from 37.5 to 32.7 Ma may reflect a greater presence of needle-leaved evergreen trees (especially Picea). The $n$-alkane proxies agree well with the explanation of the pollen diagrams, suggesting a predominance of trees and a cold and wet climate during this phase.

In Phase 3 (ca. 32.7 to $28.2 \mathrm{Ma}$, samples XJ-38 to XJ-43), $\mathrm{C}_{31}$ again dominates. $\mathrm{C}_{31} /\left(\mathrm{C}_{27}+\mathrm{C}_{29}+\mathrm{C}_{31}\right)$ largely increases, whereas $\mathrm{C}_{27} / \mathrm{C}_{31}$ and $\left(\mathrm{C}_{27}+\mathrm{C}_{29}\right) /\left(\mathrm{C}_{27}+\mathrm{C}_{29}+\mathrm{C}_{31}\right)$ ratios decrease sharply and ACL values stay relatively low after 32.7 Ma, indicating a predominance of herbaceous plants and a relatively cold climate, respectively. The odd $n$-alkane component is generally low and, in fact, drops to its lowest value $(\sim 0.05 \mu \mathrm{g} / \mathrm{g})$. The lowest content, which occurred after ca. $33 \mathrm{Ma}$ around the Eocene-Oligocene climate transition, implies that the cold climate limited plant productivity. Thus all these $n$-alkane proxies suggest the climate was probably much drier and colder than before.

The pollen record shows that drought-enduring shrub and herbaceous plants, especially Chenopodipollis and Artemisia, grew luxuriantly, whereas coniferous, temperate and warmtemperate deciduous components declined abruptly after ca. 33 Ma. Steppe vegetation replaced mountain spruce forests, suggesting the development of an arid climate and intensifying aridification.

Sediment lithology and facies provide further support for this inference. Alternate layers of gypsum and gypseous mudstone of playa were replaced by red beds of siltstone and mudstone from the flood plain at ca. $33 \mathrm{Ma}$ (Figure 2), suggesting a complete drying-up of the playa by a drier climate.

Thus, organic geochemistry and pollen-spore records collectively demonstrate a long term cooling trend from 50.2 to 28.2 Ma and an ecological event at 37.5-32.7 Ma when a vertical zonation of vegetation from lowland arid grasses, to subtropical deciduous plants at moderate elevations, to high-elevation coniferous trees. We think these changes in climate and vegetation were responses to the long term global cooling since the Eocene climatic optimum at ca. $52 \mathrm{Ma}$ $[12,54]$ (Figure 2) and probably the uplift of the surrounding mountains on the northern part of the Tibetan Plateau in the early Cenozoic. Recent tectonic studies and basin analyses do show that the Altin Tagh, Qilian Mt. and east Kunlun Mts. had an early episode of rapid uplift around 40-30 Ma [60,61]. Whereas the dry event at ca. 33 Ma was probably a direct response to the Eocene-Oligocene climate transition due to the initiation of Antarctic glaciation [12,54].

\section{Conclusions}

(1) The plant $n$-alkane proxy records obtained from early Cenozoic playa and fluvial stratigraphy spanning 50.228.23 $\mathrm{Ma}$ in the Xining Basin show three evolutionary phases of paleovegetation and paleoclimate with discrete changes occurring at ca. 37.5 and $32.7 \mathrm{Ma}$. The first $(50.2-37.5 \mathrm{Ma})$ and second $(37.5-32.7 \mathrm{Ma})$ phases are characterized by high and low values of $\mathrm{C}_{31} / \mathrm{C}_{27}$, ACL, CPI and $n$-alkane content respectively, whereas the third phase (32.7-28.23 Ma) shows a similar ratio of $\mathrm{C}_{31} / \mathrm{C}_{27}$ to the first phase, but is accompanied by low values of ACL, CPI and $n$-alkane content. These changes clearly demonstrate three phases of climatic and ecologic variations.

(2) The palynological records also demonstrate three phases of changes similar in age to the $n$-alkane proxy records presented above. The first phase presents a predominance of Ephedripites and Nitrariadites with some subtropical broad-leaf trees belonging to many taxa. The 
second phase is characterized by the sudden and spectacular appearance of conifers and shrub-grasses (Artemisia and Chenopodipollis) and a large reduction in subtropical broad-leaf trees. The third phase presents a predominance of Artemisia and Chenopodipollis and clear reductions of Ephedripites and Nitrariadites and conifer trees. These changes in vegetation indicate not only three phases of climatic change, but also that the vegetation had developed a distinct vertical zonation with arid grasses in the lowlands, subtropical deciduous plants at middle elevations, and coniferous trees in the high mountains from the second phase.

(3) Our $n$-alkane and palynological records collectively demonstrate that the paleoclimate in the Xining Basin experienced a long term cooling trend from 50.2 to $28.2 \mathrm{Ma}$ with a distinctive ecological event spanning 37.5-32.7 Ma when a vertical zonation of vegetation was established. The long term global cooling since the Eocene climatic optimum and uplift of the surrounding mountains in the northern part of the Tibetan Plateau in the early Cenozoic may be responsible for these changes.

This work was supported by the National Natural Science Foundation of China (41021001, 40920114001 and 40501079) and the Knowledge Innovation Program of the Chinese Academy of Sciences (KZCX2-YW-Q09-04).

1 Ruddiman W F, Kutzbach J E. Plateau uplift and climate change. Sci Am, 1991, 264: 66-74

2 Richter F M, Rowley D B, DePaolo D J. Sr isotope evolution of seawater: The role of tectonics. Earth Planet Sci Lett, 1992, 109: 11-23

3 Edmond J M. Himalayan tectonics, weathering processes and the strontium isotope record in marine limestones. Science, 1992, 258: 1594-1597

4 Raymo M E, Ruddiman W F. Tectonic forcing of late Cenozoic climate. Nature, 1992, 359: 117-122

5 Molnar P, England P, Martinod J. Mantle dynamics, uplift of the Tibetan Plateau, and the Indian Monsoon. Rev Geophys, 1993, 31: 357396

6 Molnar P. Mio-Pliocene growth of the Tibetan Plateau and evolution of East Asian climate. Palaeontol Electron, 2005, 8: 2-23

7 An Z S, Kutzbach J E, Prell W L, et al. Evolution of Asian monsoons and phased uplift of the Himalaya-Tibetan Plateau since Late Miocene times. Nature, 2001, 411: 62-66

8 Harris N B W. The elevation history of the Tibetan Plateau and its implications for the Asian monsoon. Palaeogeogr Palaeoclimatol Palaeoecol, 2006, 241: 4-15

9 Walker J C G, Hays P B, Kasting J F. A negative feedback mechanism for the long-term stabilization of earth's surface temperature. $\mathrm{J}$ Geophys Res, 1981, 86: 9776-9782

10 Berner R A, Lasaga A C, Garrels R M. The carbonate-silicate geochemical cycle and its effect on atmospheric $\mathrm{CO}_{2}$ over the past 100 million years. Am J Sci, 1983, 283: 641-683

11 Raymo M E, Ruddiman W F, Froelich P N. Influence of late Cenozoic mountain building on ocean geochemical cycles. Geology, 1988, 16: 649-653

12 Zachos J C, Kump L R. Carbon cycle feedbacks and the initiation of Antarctic glaciation in the earliest Oligocene. Glob Planet Change, 2005, 47: 51-66

13 Hren M T, Bookhagen B, Blisniuk P M, et al. $\delta^{18} \mathrm{O}$ and $\delta \mathrm{D}$ of streamwaters across the Himalaya and Tibetan Plateau: implications for moisture sources and paleoelevation reconstructions. Earth Planet Sci Lett, 2009, 288: 20-32

14 Cyr A, Currie B S, Rowley D B. Geochemical and stable isotopic evaluation of Fenghuoshan Group lacustrine carbonates, north-central Tibet: Implications for the paleoaltimetry of Late Eocene Tibetan Plateau. J Geol, 2005, 113: 517-533

15 Graham S A, Chamberlain C P, Yue Y J, et al. Stable isotope records of Cenozoic climate and topography, Tibetan plateau and Tarim basin. Am J Sci, 2005, 305: 101-118

16 Rowley D B, Currie B S. Palaeo-altimetry of the late Eocene to Miocene Lunpola basin, central Tibet. Nature, 2006, 439: 677-681

17 DeCelles P G, Quade J, Kapp P, et al. High and dry in central Tibet during the Late Oligocene. Earth Planet Sci Lett, 2007, 253: 389-401

18 Dupont-Nivet G, Hoorn C, Konert M. Tibetan uplift prior to the Eocene-Oligocene climate transition: Evidence from pollen analysis of the Xining Basin. Geology, 2008, 36: 987-990

19 Beek P, Melle J, Guillot S, et al. Eocene Tibetan plateau remnants preserved in the northwest Himalaya. Nature, 2009, 2: 364-368

20 Wang C S, Zhao X X, Liu Z, et al. Constraints on the early uplift history of the Tibetan Plateau. Proc Natl Acad Sci USA, 2008, 105: 4987-4992

21 Zheng D W, Zhang P Z, Wan J L, et al. Rapid exhumation at similar to $8 \mathrm{Ma}$ on the Liupan Shan thrust fault from apatite fission-track thermochronology: Implications for growth of the northeastern $\mathrm{Ti}$ betan Plateau margin. Earth Planet Sci Lett, 2006, 248: 198-208

22 Li C, Qiu Z. Early Miocene mammalian fossils of Xining Basin (in Chinese). Qinghai Verteb PalAs, 1980, 15: 198-214

23 Sun X, Zhao Y, He Z. The Oligocene-Miocene palynological assemblage from the Xining-Minhe basin (in Chinese). Geol Rev, 1984, 30: 207-216

24 Yu J, Zhang H, Lin Q, et al. Geological implications of Sporopollenites Flora from Tertiary Xining Group in Minhe County, Qinghai Province (in Chinese). Earth Sci J Chin Univ Geosci, 2003, 28: 401-405

25 Dai S, Fang X, Dupont-Nivet G, et al. Magnetostratigraphy of Cenozoic sediments from the Xining Basin: Tectonic implications for the northeastern Tibetan Plateau. J Geophys Res, 2006, 111: B11102, doi: 10.129/2005JB004187

26 Horton B K, Dupont-Nivet G, Zhou J, et al. Mesozoic-Cenozoic evolution of the Xining-Minhe and Dangchang basins, northeastern Tibetan Plateau: Magnetostratigraphic and biostratigraphic results. J Geophys Res, 2004, 109: B04402, doi:10.1029/2003JB002913

27 Cranwell P A, Eblinton G, Robinson N. Lipids of aquatic organisms as potential contributors to lacustrine sediments. Org Geochem, 1987, 11: $513-527$

28 Xie S, Chen F H, Wang Z Y, et al. Lipid distributions in loess paleosol sequences from North West China. Org Geochem, 2003, 34: 1071-1079

29 Volkmam J K, Barrett S M, Blackburn S I, et al. Allkenones in Gephyrocapsa oceanica: Implications for studies of paleoclimate. Geochim Cosmochim Acta, 1995, 59: 513-520

30 Pearson A, McNichol A P, Benitez-Nelson B C. Origins of lipid biomarkers in Santa Monica Basin surface sediment: A case study using compound-specific $\delta^{14} \mathrm{C}$ analysis. Geochim Cosmochim Acta, 2001, 65: 3123-3137

31 Lu B, Chen R H, Zhou H Y, et al. Oceanic environmental changes of subarctic Bering Sea in recent 100 years: Evidence from molecular fossils. Sci China Ser D-Earth Sci, 2005, 48: 555-564

32 Cranwell P A. Chain-length distribution of $n$-alkanes from lake sediments in relation to post-Glacial environmental change. Freshw Biol, 1973, 3: 259-265

33 Meyers P A, Ishiwatari R. Lacustrine Org Geochem-An overview of indicators of organic-matter sources and diagenesis in lake-sediments. Org Geochem, 1993, 20: 867-900

34 Sheng G Y, Cai K Q, Yang X X. Long-chain alkenones in Hotong Qagan Nur lake sediments and its paleoclimatic implications. Chinese Sci Bull, 1999, 44: 259-263

35 Xie S, Evershed R P. Peat molecular fossils recording climatic variation and organism replacement. Chinese Sci Bull, 2001, 46: 863-866

36 Zhang H C, Chang F Q, Li B, et al. Branched aliphatic alkanes of the Late Pleistocene paleolake deposits from the Qaidam Basin, NE Tibetan Plateau. Chinese Sci Bull, 2007, 52: 1248-1256

37 Xie S, Wang Z, Wang H, et al. Grassy vegetation since the last inter- 
glacial in the Loess Plateau: The molecular fossil record. Sci China Ser D-Earth Sci, 2002, 45: 53-63

38 Zhang Z H, Zhao M, Eglinton G, et al. Leaf wax lipids as paleovegetational and paleoenvironmental proxies for the Chinese Loess Plateau over the last 170 kyr. Quat Sci Rev, 2006, 25: 575-594

39 Zhang H C, Yang M S, Zhang W X, et al. Molecular fossil and paleovegetation records of paleosol S4 and adjacent loess layers in the Luochuan loess section, NW China. Sci China Ser D-Earth Sci, 2008, 51: $321-330$

40 Farrimond P, Flanagan R L. Lipid stratigraphy of a Flandrian peat bed (Northumberland, UK): Comparison with the pollen record. Holocene, 1996, 6: 69-74

41 Schwark L, Zink K, Lechterbeck J. Reconstruction of postglacial to early Holocene vegetation history in terrestrial Central Europe via cuticular lipid biomarkers and pollen records from lake sediments. Geology, 2002, 30: 463-466

42 Zhou W, Xie S, Meyers P A, et al. Reconstruction of late glacial and Holocene climate evolution in southern China from geolipids and pollen in the Dingnan peat sequence. Org Geochem, 2005, 36: $1272-1284$

43 Zhou X M, Wang Z B, Du Q. Vegetation of Qinghai Province (in Chinese). Xining: Qinghai People's Press, 1987. 1-40

44 Cranwell P A. Diagenesis of free and bound lipids in terrestrial detritus deposited in a lacustrine sediment. Org Geochem, 1981, 3: 79-89

45 Eglinton G, Hamilton R J. Leaf epicuticular waxes. Science, 1967, 156: 1322-1335

46 Rieley G, Collier R J, Jones D M, et al. The biogeochemistry of Ellesmere Lake, UK-I: Source correlation of leaf wax inputs to the sedimentary record. Org Geochem, 1991, 17: 901-912

47 Maffei M. Chemotaxonomic significance of leaf wax alkanes in the Gramineae. Biochem Syst Ecol, 1996, 24: 53-64

48 Wang Z, Xie S, Chen F. n-Alkane distribution as indicator for paleo-vegetation an example from Yuanbao S1 paleosol in Linxia, Gansu province (in Chinese). Quat Sci, 2004, 24: 235-235

49 Xie S C, Yi Y, Liu Y Y, et al. The Pleistocene vermicular red earth in South China signaling the global climatic change: The molecular fossil record. Sci China Ser D-Earth Sci, 2003, 46: 1113-1120

50 Zheng Y H, Zhou W J, Xie S C, et al. A comparative study of n-alkane biomarker and pollen records: An example from southern China. Chinese Sci Bull, 2008, 54: 1065-1072

51 Poynter J G, Farnimond P, Robinson N, et al. Aeolian-derived higher plant lipids in the marine sedimentary record: Links with palaeoclimate. In: Leinen M, Sarnthein M, eds. Paleoclimatology and Paleometeorology: Modern and Past Patterns of Global Atmospheric Transport. Dordrecht: Kluwer, 1989. 435-462

52 Simoneit B R T, Cardoso J N, Robinson N. An assessment of terrestrial higher molecular weight lipid compounds in aerosols particulate matter over the South Atlantic from about $30-70^{\circ} \mathrm{S}$. Chemosphere, 1991, 23: 447-465

53 Tripati A, Backman J, Elderfield H, et al. Eocene bipolar glaciation associated with global carbon cycle changes. Nature, 2005, 436: 341-346

54 Zachos J C, Pagani M, Sloan L. Trends, rhythms, and aberrations in global climate $65 \mathrm{Ma}$ to Present. Science, 2001, 292: 686-693

55 Hinrichs K U, Rinna J, Rullkötter J. Late Quaternary paleoenvironmental conditions indicated by marine and terrestrial molecular biomarkers in sediments from the Santa Barbara Basin, In: Wilson R C, Tharp V L, eds. Proceedings of the Fourteenth Annual Pacific Climate Workshop. California Department of Water Resources, 1997. 1-9

56 Kawamura K, Ishimura Y, Yamazaki K. Four years' observations of terrestrial lipid class compounds in marine aerosols from the western North Pacific. Glob Biogeochem Cycle, 2003, 17: 10.1029/2001GB-001810

57 Wang W M. On the origin and development of Artemisia (Asteraceae) in the geological past. Bot J Linn Soc, 2004, 145: 331-336

58 Kadereit G, Gotzek D, Jacobs S, et al. Origin and age of Australian Chenopodiaceae. Org Divers Evol, 2005, 5: 59-80

59 Miao Y F, Meng Q Q, Fang X M, et al. Origin and development of Artemisia (Asteraceae) in Asia and its implications for the uplift history of the Tibetan Plateau: A review. Quat Int, 2010, doi: 10. 1016/j. quaint.2010.08.014

60 Yin A, Rumelhart P E, Butler R, et al. Tectonic history of the Altyn Tagh fault system in northern Tibet inferred from Cenozoic sedimentation. Geol Soc Am Bull, 2002, 114: 1257-1295

Horton B K, Yin A, Spurlin M S, et al. Paleocene-Eocene syncontractional sedimentation in narrow, lacustrine-dominated basins of east-central Tibet. Geol Soc Am Bull, 2002, 114: 771-786

Open Access This article is distributed under the terms of the Creative Commons Attribution License which permits any use, distribution, and reproduction in any medium, provided the original author(s) and source are credited. 